\title{
Common Mistakes in Understanding Simple Present Tense and Present Continuous Tense Sentences: A Case Study at Non-English Department Students
}

\author{
Riyatno \\ \{riyatno@ittelkom-pwt.ac.id \\ Institut Teknologi Telkom Purwokerto \\ Jl. D.I. Panjaitan No. 128 Purwokerto, Jawa Tengah, 53147
}

\begin{abstract}
The aim of the study was to analyze the common mistakes made by Non-English Department students in understanding Simple Present Tense and Present Continuous Tense sentences. The students who joint with the class were from Telecommunications Engineering Study Program, Institut Teknologi Telkom Purwokerto in Academic Year $2018-2019$. This study involved 3 classes that contained 89 students. They were given 5 positive sentences and they had to make those sentences into negative and interrogative sentences. They had to finish doing the test in 20 minutes. The study showed that the students had made the mistakes in negative and interrogative sentences. They did not use the auxiliary verbs do, does, and be appropriately. Besides, they made mistakes when the simple present tense sentences were preceded by subject he, she, or it. Furthermore, the use of present participial verbs was still commonly found in the simple present tense sentences so that the constructions became incorrect. For this reason, teaching grammar in non-English Department study program had to be designed in such a way that they students could understand how to make statement sentences into negative and interrogative ones correctly.
\end{abstract}

Keywords: Mistake, Understanding, Simple Present Tense, Present Continuous Tense, Non-English Department. 


\title{
Kresna Social Science and Humanities Research
}

\author{
Proceedings of the International Conference On Ummah: \\ Digital Innovation, Humanities And Economy (ICU: DIHEc) 2020 \\ https://doi.org/10.30874/ksshr.21
}

\section{Introduction}

English, as a foreign language, is a compulsory subject in Indonesian education system. It has been taught at any education level, from kindergarten until higher education, based on the focus of each level. It means that students have been familiar with English even though they do not use it in their daily communications because they usually use their second language. Unfortunately, English is not the second language so that English is only knowledge for its learners.

Talking about students' knowledge on English, especially on English grammar, is still interesting to discuss because grammar is very important to avoid misunderstanding in communication. For this reason, students, especially in higher education, have to understand how to use English grammar in spoken and written communication because, as stated by Canale and Swain, grammatical competence, together with sociolinguistic competence and communication strategic competence, develops communicative competence [1]. Moreover, they have to write and to present their reports or thesis, for example, in English. Besides, more

text books are written in English so that they are compelled to master English in order to understand the books.

One of English grammar masteries that the students have to master is tense's mastery. Among those tenses, this study only focuses on Simple Present Tense and Present Continuous Tense mastery based on the fact that those tenses' patterns are mainly used both in spoken and written communications. Besides, according to Blake, "much of the material taught was already covered in high school" [2]. It means that anyone has to master the very basic tenses in English, namely how to construct negative and interrogative sentences from positive ones. For this reason, English learners have to understand "the description of the ways in which words can change their forms and can be combined into sentences" [3]. The ability to understand the word changes in Simple Present Tense and Present Continuous Tense sentences is actually important because it can change the meaning. When the construction is incorrect in terms of the word using, the readers often have to think deeply the aim and the meaning of the sentences. It means that the readers have to interpret the sentences based on the construction. It takes more time because there are some possibilities to give the meaning and the aim. In direct communication, one can clarify directly to one's partner when he or she does not understand. It, however, will be different when one has to read a letter or any other written expressions. He or she cannot ask directly to his or her partner.

\section{Research and Method}

The research was conducted to develop the technique of teaching simple present tense and present continuous tense in non-English Department so that the students could understand how to make negative and interrogative sentences from positive ones. Brown says that technique is "any of a wide variety of exercises, activities, or tasks used in the language classroom for realizing lesson objectives" [4]. Hopefully, the students could make the sentences based on the two tenses and use them both in speaking and in writing so that they were capable of communicating in basic English. Besides, their understanding in both tenses could support them for the next subject, namely English for Business and Communication.

I took three English classes for my research, namely Class A, Class B, and Class F. I did not take other classes because I did not handle them in the class so that the technique was quite different. The techniques I did to teach General English were presentation and discussion. Before they had to present their topic, I divided the class into 11 groups and each group consisted of 2 or 3 students, depending on the number of students in the class. While dividing the class into groups, I also informed them about the topics that they had to present.

To support the teaching learning process, I intentionally asked them to make WhatsApp group. The students could ask through the group or through private message so that I hoped that they could use English in real communication. This group was also designed to develop the students' motivation to learn language in the communication context, as stated by Dornyei that "during the lengthy and often tedious process of mastering a foreign/second language (L2), the learner's enthusiasm, commitment and persistence are key determinants of success or 
Proceedings of the International Conference On Ummah:

Digital Innovation, Humanities And Economy (ICU: DIHEc) 2020 https://doi.org/10.30874/ksshr.21

failure" [5].

\section{Finding and Interpretation}

The research was conducted in General English class at Telecommunications Engineering Study Program, Institut Teknologi Telkom Purwokerto, the odd semester of academic year 2018 - 2019. The subject was different from the previous one in terms of the content. Previously, English was taught in four semesters and it focused on TOEFL materials. It means that there are 8 credits during their study. Besides, the students had to get TOEFL score, at least 450 of PBT so that they passed. Since the curriculum has changed, English has 4 credits only. The content has no longer TOEFL, rather it refers to general English and English for business and communication. The subject becomes General English in the first semester and English for Business and Communication in the fourth semester. The following is the content of General English.

Table 1. The Content of General English.

\begin{tabular}{|c|c|c|}
\hline No. & Topics & Sub Topics \\
\hline 1. & Basic Structure of English Sentence & $\begin{array}{ll}\text { a. } & \text { Part of Speech } \\
\text { b. } & \text { Subject Verb Agreement }\end{array}$ \\
\hline 2. & Simple Present Tense & $\begin{array}{ll}\text { a. } & \text { Positive Sentence } \\
\text { b. Negative Sentence } \\
\text { c. Interrogative Sentence }\end{array}$ \\
\hline 3. & Present Continuous Tense & $\begin{array}{ll}\text { a. Positive Sentence } \\
\text { b. Negative Sentence } \\
\text { c. Interrogative Sentence }\end{array}$ \\
\hline 4. & Simple Past Tense & $\begin{array}{ll}\text { a. } & \text { Positive Sentence } \\
\text { b. Negative Sentence } \\
\text { c. }\end{array}$ \\
\hline 5. & Past Continuous Tense & $\begin{array}{ll}\text { a. } & \text { Positive Sentence } \\
\text { b. } & \text { Negative Sentence } \\
\text { c. } & \text { Interrogative Sentence }\end{array}$ \\
\hline 6. & Simple Future Tense & $\begin{array}{ll}\text { a. } & \text { Positive Sentence } \\
\text { b. Negative Sentence } \\
\text { c. Interrogative Sentence }\end{array}$ \\
\hline 7. & Modal Verbs & a. Modal Verbs \\
\hline 8. & Mid Term Exam & \\
\hline 9. & Reading Technique & $\begin{array}{ll}\text { a. } & \text { Skimming }\end{array}$ \\
\hline 10. & Reading Technique & a. Scanning \\
\hline 11. & Reading Technique & a. $\quad$ Reading Exercise \\
\hline 12. & Students' Presentation & $\begin{array}{l}\text { a. Presentation based on a given } \\
\text { topic }\end{array}$ \\
\hline 13. & Students' Presentation & $\begin{array}{l}\text { a. Presentation based on a given } \\
\text { topic }\end{array}$ \\
\hline 14. & Writing Short Paragraph & $\begin{array}{l}\text { a. Writing Short Paragraph based } \\
\text { on picture }\end{array}$ \\
\hline 15. & Writing Short Paragraph & $\begin{array}{l}\text { a. Writing Short Paragraph based } \\
\text { on video }\end{array}$ \\
\hline
\end{tabular}


Proceedings of the International Conference On Ummah:

Digital Innovation, Humanities And Economy (ICU: DIHEc) 2020

https://doi.org/10.30874/ksshr.21

\section{6. $\quad$ Final Exam}

Based on the content of General English, each group had to present the topic in front of the class. Because the subject referred to all skills in language learning, the presentation about tenses could not be discussed in detail. There was no exercise in understanding the tenses, namely, how to comprehend the relationship between subject and verb in the sentence and how to change the verb when the sentence had to be made into negative and interrogative sentences. It is in line with the statement of Smith and Taylor (in Brindley, 1994), "while many English teachers no longer teach grammar through exercises, they still claim to be supporting students' grammatical understanding by doing it "in context"' [6].

The time in the class was divided into three sections, namely, students' presentation, discussion, and lecturer's clarification. The lecturer clarified the improper explanations relating to the topic presented by the students. In this case, I tried to make the confusing explanations clear so that they really understood the material. To know their understanding, I gave them the quiz in the fourth meeting, seventh meeting, eleventh meeting, and the fourteenth meeting. In line with the first quiz conducted in the fourth meeting in which the students had to change the positive into negative and interrogative, I designed the quiz as follows:

Table 2. The Quiz of General English

\begin{tabular}{|l|l|l|}
\hline No. & \multicolumn{1}{|c|}{ Quiz } & \multicolumn{1}{c|}{ Category } \\
\hline 1. & His father speaks German on the weekends. & Positive Simple Present Tense \\
\hline 2. & The teachers discuss the lessons in the office. & Positive Simple Present Tense \\
\hline 3. & My sons are in the movie. & Positive Simple Present Tense \\
\hline 4. & He is listening to music at the moment. & Positive Present Continuous Tense \\
\hline 5. & $\begin{array}{l}\text { My sisters are writing their thesis this } \\
\text { semester. }\end{array}$ & Positive Present Continuous Tense \\
\hline
\end{tabular}

I conducted the quiz above as a formative evaluation. According to Nation and Macalister, "a formative evaluation has the purpose of forming or shaping the course to improve it" [7]. The students had to change the positive sentence into negative and interrogative sentences. Each number had two answers and the students had 10 numbers. If the students could make a correct answer, they got 10 because the score of each number was 10 . The result of the quiz can be seen in the following:

Table 3. The Result of the Quiz

\begin{tabular}{|l|c|c|c|c|c|c|c|c|c|c|c|c|}
\hline \multirow{2}{*}{ No. } & Students' & \multicolumn{10}{|c|}{ Students' Answer } & \multirow{2}{*}{ Score } \\
\cline { 3 - 16 } & Number & $1-$ & $1 ?$ & $2-$ & $2 ?$ & $3-$ & $3 ?$ & $4-$ & $4 ?$ & $5-$ & $5 ?$ & \\
\hline 1. & 19101001 & 0 & 0 & 1 & 1 & 1 & 1 & 0 & 0 & 1 & 1 & 60 \\
\hline 2. & 19101002 & 1 & 0 & 1 & 0 & 0 & 1 & 0 & 1 & 0 & 1 & 50 \\
\hline 3. & 19101003 & 1 & 1 & 1 & 1 & 1 & 1 & 1 & 1 & 1 & 1 & 100 \\
\hline 4. & 19101004 & 0 & 0 & 0 & 0 & 0 & 0 & 0 & 0 & 0 & 0 & 0 \\
\hline 5. & 19101005 & 0 & 0 & 0 & 0 & 1 & 1 & 0 & 1 & 0 & 0 & 30 \\
\hline 6. & 19101006 & 0 & 0 & 1 & 0 & 0 & 0 & 0 & 0 & 0 & 0 & 10 \\
\hline 7. & 19101007 & 1 & 1 & 1 & 1 & 1 & 1 & 1 & 1 & 1 & 1 & 100 \\
\hline
\end{tabular}


Kresna Social Science and Humanities Research

Proceedings of the International Conference On Ummah:

Digital Innovation, Humanities And Economy (ICU: DIHEc) 2020

https://doi.org/10.30874/ksshr.21

\begin{tabular}{|c|c|c|c|c|c|c|c|c|c|c|c|c|}
\hline 8. & 19101008 & 0 & 1 & 0 & 0 & 1 & 0 & 1 & 0 & 1 & 0 & 40 \\
\hline 9. & 19101009 & 1 & 1 & 0 & 0 & 0 & 0 & 0 & 0 & 0 & 0 & 20 \\
\hline 10. & 19101010 & 0 & 0 & 1 & 0 & 1 & 0 & 0 & 0 & 1 & 0 & 30 \\
\hline 11. & 19101011 & 0 & 0 & 1 & 1 & 0 & 0 & 1 & 1 & 0 & 0 & 40 \\
\hline 12. & 19101012 & 0 & 0 & 1 & 0 & 0 & 0 & 0 & 0 & 0 & 0 & 10 \\
\hline 13. & 19101013 & 1 & 1 & 1 & 1 & 1 & 1 & 1 & 1 & 1 & 1 & 100 \\
\hline 14. & 19101014 & 0 & 0 & 0 & 0 & 1 & 0 & 1 & 0 & 1 & 1 & 40 \\
\hline 15. & 19101015 & 0 & 1 & 1 & 0 & 0 & 0 & 0 & 0 & 0 & 0 & 20 \\
\hline 16. & 19101016 & 0 & 0 & 1 & 1 & 1 & 1 & 1 & 1 & 1 & 1 & 80 \\
\hline 17. & 19101017 & 0 & 0 & 0 & 0 & 0 & 0 & 1 & 0 & 0 & 0 & 10 \\
\hline 18. & 19101018 & 1 & 1 & 1 & 1 & 1 & 1 & 1 & 1 & 1 & 1 & 100 \\
\hline 19. & 19101019 & 0 & 0 & 0 & 0 & 1 & 1 & 0 & 0 & 0 & 0 & 20 \\
\hline 20. & 19101020 & 0 & 0 & 0 & 0 & 1 & 1 & 1 & 1 & 1 & 0 & 50 \\
\hline 21. & 19101021 & 0 & 0 & 1 & 1 & 1 & 1 & 1 & 1 & 1 & 1 & 80 \\
\hline 22. & 19101022 & 1 & 1 & 1 & 1 & 1 & 1 & 1 & 1 & 1 & 1 & 100 \\
\hline 23. & 19101023 & 1 & 1 & 0 & 0 & 0 & 0 & 0 & 1 & 0 & 0 & 30 \\
\hline 24. & 19101024 & 0 & 0 & 1 & 0 & 1 & 1 & 0 & 1 & 1 & 1 & 60 \\
\hline 25. & 19101025 & 0 & 0 & 1 & 1 & 1 & 1 & 0 & 0 & 0 & 0 & 40 \\
\hline 26. & 19101026 & 0 & 1 & 1 & 1 & 1 & 1 & 1 & 1 & 0 & 0 & 70 \\
\hline 27. & 19101028 & 1 & 1 & 1 & 1 & 1 & 1 & 1 & 1 & 1 & 1 & 100 \\
\hline 28. & 19101029 & 1 & 1 & 1 & 1 & 1 & 1 & 1 & 1 & 1 & 1 & 100 \\
\hline 29. & 19101030 & 0 & 0 & 0 & 0 & 1 & 0 & 1 & 1 & 0 & 0 & 30 \\
\hline 30. & 19101031 & 0 & 0 & 0 & 0 & 0 & 0 & 1 & 0 & 1 & 1 & 30 \\
\hline 31. & 19101033 & 1 & 0 & 1 & 0 & 0 & 0 & 0 & 0 & 0 & 0 & 20 \\
\hline 32. & 19101034 & 0 & 0 & 1 & 0 & 0 & 1 & 0 & 0 & 0 & 1 & 30 \\
\hline 33. & 19101035 & 1 & 1 & 1 & 1 & 1 & 1 & 0 & 0 & 0 & 1 & 70 \\
\hline 34. & 19101036 & 0 & 1 & 1 & 1 & 1 & 1 & 1 & 1 & 1 & 1 & 90 \\
\hline 35. & 19101038 & 0 & 0 & 0 & 0 & 1 & 1 & 1 & 1 & 1 & 1 & 60 \\
\hline 36. & 19101039 & 1 & 1 & 0 & 0 & 1 & 1 & 1 & 0 & 1 & 0 & 60 \\
\hline 37. & 19101042 & 0 & 0 & 0 & 1 & 0 & 0 & 1 & 0 & 0 & 1 & 30 \\
\hline 38. & 19101043 & 1 & 0 & 1 & 1 & 1 & 1 & 1 & 1 & 1 & 1 & 90 \\
\hline 39. & 19101044 & 1 & 1 & 1 & 1 & 1 & 1 & 1 & 1 & 1 & 1 & 100 \\
\hline 40. & 19101045 & 0 & 0 & 0 & 0 & 0 & 0 & 0 & 1 & 0 & 0 & 10 \\
\hline 41. & 19101046 & 1 & 1 & 0 & 1 & 1 & 0 & 1 & 1 & 0 & 0 & 60 \\
\hline 42. & 19101047 & 0 & 0 & 0 & 0 & 1 & 0 & 1 & 1 & 0 & 0 & 30 \\
\hline 43. & 19101048 & 0 & 0 & 1 & 0 & 0 & 0 & 1 & 1 & 0 & 0 & 30 \\
\hline 44. & 19101049 & 0 & 0 & 1 & 1 & 0 & 0 & 1 & 0 & 1 & 1 & 50 \\
\hline 45. & 19101050 & 0 & 0 & 0 & 0 & 1 & 1 & 1 & 1 & 1 & 1 & 60 \\
\hline 46. & 19101051 & 0 & 0 & 1 & 1 & 1 & 1 & 1 & 1 & 1 & 1 & 80 \\
\hline 47. & 19101052 & 0 & 0 & 1 & 0 & 1 & 1 & 0 & 0 & 0 & 1 & 40 \\
\hline 48. & 19101053 & 0 & 0 & 1 & 1 & 1 & 1 & 1 & 1 & 1 & 1 & 80 \\
\hline 49. & 19101054 & 1 & 1 & 1 & 1 & 1 & 1 & 1 & 1 & 1 & 1 & 100 \\
\hline
\end{tabular}


Kresna Social Science and Humanities Research

Proceedings of the International Conference On Ummah:

Digital Innovation, Humanities And Economy (ICU: DIHEc) 2020

https://doi.org/10.30874/ksshr.21

\begin{tabular}{|c|c|c|c|c|c|c|c|c|c|c|c|c|}
\hline 50. & 19101059 & 1 & 0 & 0 & 0 & 1 & 0 & 1 & 0 & 0 & 0 & 30 \\
\hline 51. & 19101060 & 0 & 1 & 0 & 0 & 1 & 0 & 0 & 0 & 1 & 1 & 40 \\
\hline 52. & 19101063 & 0 & 0 & 1 & 1 & 0 & 0 & 1 & 1 & 1 & 1 & 60 \\
\hline 53. & 19101064 & 0 & 0 & 0 & 0 & 1 & 1 & 0 & 1 & 1 & 1 & 50 \\
\hline 54. & 19101066 & 0 & 0 & 0 & 0 & 1 & 1 & 1 & 1 & 1 & 1 & 60 \\
\hline 55. & 19101067 & 1 & 1 & 1 & 1 & 1 & 0 & 1 & 0 & 0 & 0 & 60 \\
\hline 56. & 19101068 & 0 & 0 & 0 & 0 & 1 & 0 & 1 & 1 & 1 & 1 & 50 \\
\hline 57. & 19101070 & 1 & 1 & 1 & 1 & 1 & 1 & 1 & 1 & 1 & 1 & 100 \\
\hline 58. & 19101177 & 0 & 0 & 0 & 0 & 1 & 1 & 1 & 0 & 0 & 0 & 30 \\
\hline 59. & 19101178 & 0 & 1 & 1 & 1 & 1 & 1 & 1 & 1 & 1 & 1 & 90 \\
\hline 60. & 19101179 & 0 & 0 & 0 & 1 & 0 & 0 & 0 & 0 & 0 & 0 & 10 \\
\hline 61. & 19101180 & 0 & 0 & 0 & 0 & 1 & 0 & 1 & 1 & 1 & 0 & 40 \\
\hline 62. & 19101181 & 1 & 0 & 0 & 0 & 1 & 1 & 1 & 0 & 0 & 0 & 40 \\
\hline 63. & 19101182 & 0 & 0 & 0 & 0 & 0 & 0 & 0 & 0 & 0 & 0 & 0 \\
\hline 64. & 19101183 & 0 & 0 & 0 & 0 & 0 & 0 & 1 & 1 & 1 & 1 & 40 \\
\hline 65. & 19101184 & 1 & 1 & 0 & 0 & 1 & 1 & 1 & 1 & 1 & 1 & 80 \\
\hline 66. & 19101185 & 0 & 0 & 0 & 0 & 1 & 1 & 1 & 1 & 1 & 1 & 60 \\
\hline 67. & 19101186 & 1 & 0 & 0 & 0 & 0 & 0 & 0 & 0 & 0 & 0 & 10 \\
\hline 68. & 19101187 & 1 & 1 & 1 & 1 & 1 & 1 & 1 & 1 & 1 & 1 & 100 \\
\hline 69. & 19101188 & 0 & 0 & 0 & 0 & 0 & 0 & 0 & 0 & 0 & 0 & 0 \\
\hline 70. & 19101189 & 0 & 0 & 1 & 1 & 1 & 1 & 1 & 1 & 1 & 1 & 80 \\
\hline 71. & 19101190 & 0 & 0 & 0 & 1 & 0 & 0 & 0 & 0 & 0 & 0 & 10 \\
\hline 72. & 19101191 & 0 & 0 & 1 & 1 & 0 & 0 & 1 & 0 & 0 & 0 & 30 \\
\hline 73. & 19101192 & 1 & 1 & 1 & 1 & 1 & 1 & 1 & 1 & 1 & 1 & 100 \\
\hline 74. & 19101193 & 0 & 0 & 0 & 0 & 0 & 0 & 1 & 0 & 0 & 0 & 10 \\
\hline 75. & 19101194 & 0 & 0 & 0 & 0 & 1 & 1 & 1 & 1 & 0 & 0 & 40 \\
\hline 76. & 19101195 & 0 & 0 & 1 & 1 & 1 & 1 & 1 & 1 & 1 & 0 & 70 \\
\hline 77. & 19101196 & 0 & 0 & 0 & 0 & 0 & 1 & 0 & 1 & 0 & 0 & 20 \\
\hline 78. & 19101197 & 0 & 0 & 0 & 0 & 1 & 1 & 1 & 1 & 1 & 1 & 60 \\
\hline 79. & 19101198 & 0 & 0 & 0 & 0 & 1 & 1 & 1 & 1 & 0 & 0 & 40 \\
\hline 80. & 19101199 & 0 & 0 & 0 & 1 & 1 & 1 & 0 & 0 & 0 & 1 & 40 \\
\hline 81. & 19101200 & 1 & 1 & 1 & 1 & 1 & 1 & 1 & 1 & 1 & 1 & 100 \\
\hline 82. & 19101201 & 1 & 1 & 1 & 1 & 1 & 1 & 1 & 1 & 1 & 1 & 100 \\
\hline 83. & 19101203 & 0 & 0 & 0 & 0 & 1 & 1 & 0 & 1 & 1 & 0 & 40 \\
\hline 84. & 19101204 & 0 & 0 & 1 & 0 & 0 & 1 & 0 & 1 & 1 & 0 & 40 \\
\hline 85. & 19101205 & 0 & 0 & 1 & 1 & 1 & 1 & 1 & 1 & 0 & 0 & 60 \\
\hline 86. & 19101206 & 0 & 0 & 0 & 0 & 1 & 1 & 1 & 1 & 0 & 1 & 50 \\
\hline 87. & 19101207 & 1 & 0 & 0 & 0 & 0 & 0 & 1 & 1 & 0 & 0 & 30 \\
\hline 88. & 19101208 & 0 & 0 & 1 & 1 & 1 & 1 & 1 & 1 & 1 & 1 & 80 \\
\hline \multirow[t]{2}{*}{89.} & 19101209 & 0 & 0 & 0 & 1 & 1 & 0 & 0 & 1 & 0 & 0 & 30 \\
\hline & $\begin{array}{c}\text { Total and } \\
\text { Average }\end{array}$ & 28 & 27 & 45 & 40 & 61 & 53 & 59 & 56 & 47 & 46 & 51.91 \\
\hline
\end{tabular}




\section{Kresna Social Science and Humanities Research}

Proceedings of the International Conference On Ummah:

Digital Innovation, Humanities And Economy (ICU: DIHEc) 2020

https://doi.org/10.30874/ksshr.21

Based on the table above, the average score was 51.91 and most of the students got difficulty to make negative and interrogative sentences. Their difficulties were mostly found in their understanding on the relationship between subject and verb in the sentence. They did not change the verbs when the sentence became negative and interrogative sentences, especially in Simple Present Tense. Actually, when students want to know how to make a positive sentence into negative and interrogative sentences, firstly, they have to know the subject of the sentence if the subject is single or plural. If the subject belongs to third person singular, then, they have to use does not for the negative sentence. Besides, they have to change the verb into basic form. The explanation on the students' responses can be seen in the following.

For question number 1, namely, "His father speaks German on the weekends," the answer for negative sentence had to be "His father does not speak German on the weekends," and for interrogative sentence had to be "Does his father speak German on the weekends?" The students should have understood that they had to add auxiliary verb does and negative marker not after the subject. They also had to change the verb speaks into basic verb speak. For the interrogative answer, the students were still confused on how to use auxiliary verbs do, does, are, and is. Besides, the verb should have been changed into basic verb. Some students used question words to make interrogative sentence and the construction was improperly used. The common incorrect responses are showed as follows:

Table 4. The Common Incorrect Responses of Quiz 1

\begin{tabular}{|l|l|}
\hline No. & \multicolumn{1}{|c|}{ Responses } \\
\hline 1. & His father does not speaks German on the weekends. \\
\hline 2. & His father don't speak German on the weekends. \\
\hline 3. & His father do not speaks German on the weekends. \\
\hline 4. & His father not speaks German on the weekends. \\
\hline 5. & Does his father speaks German on the weekends? \\
\hline 6. & Is his father speaks German on the weekends? \\
\hline 7. & When his father speaks German? \\
\hline 8. & Do his father speaks German on the weekends? \\
\hline
\end{tabular}

For question number 2, namely, "The teachers discuss the lessons in the office," the answer for negative sentence had to be "The teachers do not discuss the lessons in the office," and for interrogative sentence had to be "Do the teachers discuss the lessons in the office?" The students should have understood that they had to add auxiliary verb do and negative marker not after the subject. They did not have to change the verb discuss. For the interrogative answer, the students were still confused on how to use auxiliary verbs does, are, and question word. Besides, the verb should not have been changed into basic verb. Some students used question words to make interrogative sentence and the construction was improperly used. The common incorrect responses are showed as follows:

Table 5. The Common Incorrect Responses of Quiz 2

\begin{tabular}{|l|l|}
\hline No. & \multicolumn{1}{|c|}{ Responses } \\
\hline 1. & The teacher does not discuss the lessons in the office. \\
\hline 2. & The teacher don't discuss the lesson in the office. \\
\hline 3. & The teachers does not discuss the lessons in the office. \\
\hline 4. & The teacher not discuss the lessons in the office. \\
\hline
\end{tabular}




\section{Kresna Social Science and Humanities Research}

Proceedings of the International Conference On Ummah:

Digital Innovation, Humanities And Economy (ICU: DIHEc) 2020

https://doi.org/10.30874/ksshr.21

\begin{tabular}{|l|l|}
\hline 5. & Are the teachers discuss the lessons in the office? \\
\hline 6. & Where the teacher discuss the lessons? \\
\hline 7. & In the office they discuss the lessons? \\
\hline 8. & Does the teachers discuss the lessons in the office? \\
\hline
\end{tabular}

For question number 3, namely, "My sons are in the movie," the answer for negative sentence had to be "My sons are not in the movie," and for interrogative sentence had to be "Are my sons in the movie?" The students should have understood that they had to add negative marker not after auxiliary verb are. They did not have to change the verb. For the interrogative answer, the students were still confused on how to use auxiliary verbs does, are, and question word. Besides, the verb should not have been changed into basic verb. Some students used question words to make interrogative sentence and the construction was improperly used. The common incorrect responses are showed as follows:

Table 6. The Common Incorrect Responses of Quiz 3

\begin{tabular}{|l|l|}
\hline No. & \multicolumn{1}{|c|}{ Responses } \\
\hline 1. & My sons do not are in the movie. \\
\hline 2. & My sons does not are in the movie. \\
\hline 3. & My sons does not in the movie. \\
\hline 4. & My sons are does not in the movie. \\
\hline 5. & Why my sons in the movie? \\
\hline 6. & Are not my sons in the movie? \\
\hline 7. & Are my son in the movie? \\
\hline 8. & Do my sons in the movie? \\
\hline
\end{tabular}

For question number 4, namely, "He is listening to music at the moment," the answer for negative sentence had to be "He is not listening to music at the moment," and for interrogative sentence had to be "Is he listening to music at the moment?" The students should have understood that they had to add negative marker not after auxiliary verb is. They did not have to change the verb. For the interrogative answer, the students were still confused on how to use auxiliary verbs do, are, and question word. Besides, the verb should not have been changed into basic verb. Some students used question words to make interrogative sentence and the construction was improperly used. The common incorrect responses are showed as follows:

Table 7. The Common Incorrect Responses of Quiz 4

\begin{tabular}{|c|l|}
\hline No. & \\
\hline 1. & He is does not listening to music at the moment. \\
\hline 2. & He is aren't listening to music at the moment. \\
\hline 3. & He is do not are listening to music at the moment. \\
\hline 4. & He does not to listening music at the moment. \\
\hline 5. & Who is listening to music at the moment? \\
\hline 6. & He listening music at the moment? \\
\hline 7. & Do he is listening to music at the moment? \\
\hline 8. & Does listening he is to music at the moment? \\
\hline
\end{tabular}




\section{Kresna Social Science and Humanities Research}

Proceedings of the International Conference On Ummah:

Digital Innovation, Humanities And Economy (ICU: DIHEc) 2020

https://doi.org/10.30874/ksshr.21

For question number 5, namely, "My sisters are writing their thesis this semester," the answer for negative sentence had to be "My sisters are not writing their thesis this semester," and for interrogative sentence had to be "Are my sisters writing their thesis this semester?" or "Are your sisters writing their thesis this semester?" The students should have understood that they had to add negative marker not after auxiliary verb are. They did not have to change the verb. For the interrogative answer, the students were still confused on how to use auxiliary verbs do, are, and question word. Besides, the verb should not have been changed into basic verb. Some students used question words to make interrogative sentence and the construction was improperly used. The common incorrect responses are showed as follows:

Table 8. The Common Incorrect Responses of Quiz 5

\begin{tabular}{|c|l|}
\hline No. & \multicolumn{1}{|c|}{ Responses } \\
\hline 1. & My sisters do not are writing their thesis this semester. \\
\hline 2. & My sisters doesn't writing their thesis this semester. \\
\hline 3. & My sister not writing their thesis this semester. \\
\hline 4. & My sister doesn't are writing their thesis this semester. \\
\hline 5. & Do my sisters writing their thesis this semester? \\
\hline 6. & What is my sister doing this semester? \\
\hline 7. & Are thesis this semester writing my sister? \\
\hline 8. & My sister are writing thesis? \\
\hline
\end{tabular}

\section{Conclusion}

As stated above that the aim of the study was to analyze the common mistakes made by Non-English Department students in understanding Simple Present Tense and Present Continuous Tense sentences. The students had made the mistakes in negative and interrogative sentences. They did not use the auxiliary verbs do, does, and be appropriately. Besides, they made mistakes when the simple present tense sentences were preceded by subject he, she, or it. Furthermore, the use of present participial verbs was still commonly found in the simple present tense sentences so that the constructions became incorrect. For this reason, teaching grammar in non-English Department study program has to be designed in such a way that they students can understand how to make statement sentences into negative and interrogative ones correctly.

\section{References}

[1] Michael Canale and M. Swain. Theoretical Bases of Communicative Approaches to Second Language Teaching and Testing. Toronto: Ontario Ministry of Education; 1980.

[2] Robert J. Blake. Brave New Digital Classromm: Technology and Foreign Language Learning. Washington: Georgetown University Press; 2008. 2

[3] Jeremy Harmer. The Practice of English Language Teaching. $3^{\text {rd }}$ Edition. Harlow: Pearson; 2001.12

[4] H. Douglas Brown. Teaching by Principles: An Interactive Approach to Language Pedagogy. $2^{\text {nd }}$ Edition. San Francisco: Longman; 2000. 16

[5] Zoltan Dornyei. Motivational Strategies in the Language Classroom. Cambridge: Cambridge University Press, 2001. 5

[6] Susan Brindley (Ed.). Teaching English. London: Routledge; 1994. 204

[7] I.S.P. Nation and John Macalister. Language Curriculum Design. New York: Routledge; 2010. 125 